\title{
Vitamin-C Treated Haematology Assessment of Swiss Albino Mice (Mus musculus)
}

\author{
Banaja Prakashini Samantaray ${ }^{1}$, Siba Prasad Parida ${ }^{1, *(D)}$ \\ 1 Department of Zoology, School of Applied Sciences Centurion University of Technology and Management, Odisha, \\ India \\ * Correspondence: paridasp@gmail.com;
}

Scopus Author ID 57197747626

Received: 11.07.2020; Revised: 27.08.2020; Accepted: 30.08.2020; Published: 1.09.2020

\begin{abstract}
Vitamin $\mathrm{C}$ is an essential dietary supplement that plays a vital role in battling health conditions. The antioxidant has positive effects on the functioning of the body. The purpose of this study is to investigate the outcome of varying concentrations of Vitamin $\mathrm{C}$ on the hematological parameters of Swiss Albino mice. Four albino mice were separated and accommodated in similar caging conditions. Three of them were orally administered with $250 \mathrm{mg} / \mathrm{kg}, 500 \mathrm{mg} / \mathrm{kg}$, and $1000 \mathrm{mg} / \mathrm{kg}$ Vitamin $\mathrm{C}$ powder, along with their diet. The fourth one was kept as control, in order to provide a standard value for future comparison. After 30 days of administration of the Vitamin C, the red blood cell count, the white blood cell count, the hemoglobin concentration, the platelet cell count, and the packed cell volume of the blood samples were tested.
\end{abstract}

Keywords: vitamin C; haematology; albino mice.

(C) 2020 by the authors. This article is an open-access article distributed under the terms and conditions of the Creative Commons Attribution (CC BY) license (https://creativecommons.org/licenses/by/4.0/).

\section{Introduction}

Vitamin $\mathrm{C}$ is considered to be in all products with an evident ascorbic acid constituent. It doesn't only involve the acid but also its isomers as they are interchangeable [1]. Vitamin C is said to be an excellent antioxidant with its eminent take in electron transfer, immune response, cell metabolism, enzymatic reactions [2], and oxidation-reduction balance in the body. The vitamin has a vast therapeutic effect, it has been tested for disease prevention, and its influence has been observed for the treatment of health conditions as extreme as cancer [3]. Prevention of inactivation of other antioxidants is also checked upon by Vitamin C [4]. Promotion of absorption of iron in the small intestine[5] and oxidative damage diminishing in vascular walls [6] and are also important reasons why the compound has been the subject of the study. Favorable dosing is important for the proper mediation of studies that involve Vitamin C [7]. A mathematical model had also been devised to express the consistent effectiveness of Vitamin $\mathrm{C}$ when used for treatment for medical purposes [8]. In cases of infection, the Vitamin $\mathrm{C}$ requirement of the patient's body increases; hence external administration is also encouraged [9]. The experiment uses Swiss Albino mice as the animal model because of its evolutionary connectivity and similar physiology to that of human beings [10]. The genetic correspondence between the two species has been illustrated by various genomic studies [11]. Mice have been used as the experimental subject for disease and research, going as far as gnotobiology to as familiar as physiology[12]. Vitamin $\mathrm{C}$ and other antioxidants have been tested for their possible effect on the lifespan of the model organisms, thus making it an excellent choice for this hematological study [13]. Since mice models are used by 
pharmaceutical and drug research laboratories [14] to determine the effect of their production, the mice with prolonged health can be used to find the long term effect of any drug and their chronic side effects, if any. The hematological analysis also helps in the establishment of the physical health status [15-18]. The comparison to the control group is essential to ascertain if the animal is responding differently to the feed being provided. Vitamin $\mathrm{C}$ has also been researched for its efficiency as a possible treatment for COVID-19, because of its inexpensiveness and positive effects on the treatment of infections, in critically ill or ventilated patients [19]. The study aims to classify if the addition of vitamin $\mathrm{C}$ to the diet of the mice will indicate better health in it.

\section{Materials and Methods}

Forty-four-week old adult Swiss Albino mice between the weights of 44-55g were procured from the Animal House at the Department of Pharmacology, Centurion University of Technology and Management, Odisha, India. Approval of Institutional Animal Ethics Committee (IAEC) Registration No-2024/PO/Rc/S/18/CPCSEA dated 07/08/2018.The experiment was conducted at the laboratory of the Department of Zoology at the university. The forty mice were randomly divided into four groups for the experiment work. The animals were housed for 60 days. They were kept in conventional laboratory cages with the ball bearing water bottle to place water at their disposal for consumption on-demand [20]. They were fed three times a day with a mixture of various flower seeds, lentils, vegetables, and fruits. They were all fed similar diets, with the only difference being the Vitamin $\mathrm{C}$ addition to their diet at different doses $(250 \mathrm{mg} / \mathrm{kg}, 500 \mathrm{mg} / \mathrm{kg}$, and $1000 \mathrm{mg} / \mathrm{kg})$. One group was fed with no vitamin C and was to become the control group. Another group was fed with $250 \mathrm{mg} / \mathrm{kg}$ dose of Vitamin $\mathrm{C}$ with no other addition to their diet. The process was similar for the $500 \mathrm{mg} / \mathrm{kg}$ and the $1000 \mathrm{mg} / \mathrm{kg}$ dose as well.

\subsection{Hematological analysis.}

After the commencement of 60 days of dosing, the blood samples were extracted from the animal, from the orbital sinus of the mice [21-22] with the help of a capillary tube, into an EDTA vial. The total red blood cell count and the total white blood cell count were done with the help of a hemocytometer. The differential counts of lymphocytes were done by staining it with Giemsa's stain. The hemoglobin was calculated with the help of Sahli's haemoglobinometer, and the Packed Cell Volume was determined by the Wintrobe tube.

\subsection{Statistical analysis.}

The Mean Corpuscular Volume, The Mean Corpuscular Haemoglobin, and the Mean Corpuscular Haemoglobin Concentration were calculated from their respective formulas. The data was presented after statistical analysis in the form of Mean \pm Standard Deviation, which was evaluated using MS Excel.

\section{Results and Discussion}

The results obtained after carrying out the experiment had the above-mentioned parameters in them. The RBC count for the control group was determined to be $4.03 \pm 0.208$ (Table 1). The second group for the experiment, which had $250 \mathrm{mg} / \mathrm{kg}$ of the dosage, has a little elevated RBC count of $4.50 \pm 0.293$ (Table 1). The third group, with the $500 \mathrm{mg} / \mathrm{kg}$ dose had its 
RBC count further elevated to be $4.680 \pm 0.190$ (Table 1). Lastly, the group with the highest dosage, $1000 \mathrm{mg} / \mathrm{kg}$, also followed suit with the elevation and had a count of $4.84 \pm 0.243$ (Table 1 ), which is higher than all the other groups tested. The WBC count was next in line, and the lowest count was observed in the highest dosage, and the observed value was $7.76 \pm 0.44$ (Table 1). The next was the level of the $500 \mathrm{mg} / \mathrm{kg}$ dosage, which was higher than the level of the $1000 \mathrm{mg} / \mathrm{kg}$ dosage and was $7.80 \pm 0.41$ (Table 1 ). The $250 \mathrm{mg} / \mathrm{kg}$ dosage had the WBC count a bit higher, and that was8.06 \pm 0.39 (Table 1). The highest level was observed in the control group and its was $8.16 \pm 0.39$ (Table 1).

The Haemoglobin count or $\mathrm{Hb}$ in the control group was observed to be $12.52 \pm 0.7 \mathrm{~g} / \mathrm{dl}$ (Table 1). The Hb level in the treatment group of $250 \mathrm{mg} / \mathrm{kg}$ was highest than that of the control group, and it was $12.87 \pm 0.41 \mathrm{~g} / \mathrm{dl}$ (Table 1 ). The $500 \mathrm{mg} / \mathrm{kg}$ group had a higher observation, and the value was $13.14 \pm 0.57 \mathrm{~g} / \mathrm{dl}$ (Table 1 ). The highest $\mathrm{Hb}$ count was seen in the group with $1000 \mathrm{mg} / \mathrm{kg}$ dose of Vitamin C, and it was $13.40 \pm 0.47 \mathrm{~g} / \mathrm{dl}$ (Table 1). The differential count of the blood samples had been done, and the values for the control group had Neutrophils at $17 \pm 3 \%$ (Table 1), Eosinophils at $0.2 \pm 0.1 \%$ (Table 1), 0\% Basophils (Table 1), Lymphocytes at $80 \pm 3 \%$ (Table 1) and no Monocytes. The differential count values for the $250 \mathrm{mg} / \mathrm{kg}$ group were somewhat the same with Neutrophils at $17 \pm 3 \%$ (Table 1), Eosinophils at $0.1 \pm 0.1 \%$ (Table 1), 0 Basophils (Table 1), Lymphocytes at $81 \pm 3 \%$ (Table 1), and no Monocytes. A slight elevation was observed in the values of the $500 \mathrm{mg} / \mathrm{kg}$ group the Neutrophils were at $19 \pm 3 \%$ (Table 1), no Eosinophils, 0 Basophils (Table 1), Lymphocytes at $83 \pm 3 \%$ (Table 1), and no Monocytes. The group with $1000 \mathrm{mg} / \mathrm{kg}$ treatment has the highest values and the Neutrophils at 20 $\pm 3 \%$ (Table 1), Eosinophils at $0 \%$ (Table 1), 0 Basophils, Lymphocytes at $83 \pm 3 \%$ (Table 1 ), and no Monocytes. The Packed Cell Volume of the test subjects differed as well. The lowest observation was taken in the control group with the $50.9 \pm 1.6 \%$ PCV (Table 1). The volume in the second group with $250 \mathrm{mg} / \mathrm{kg}$ dosage was $51.6 \pm 1.6 \%$ (Table 1). The third group had the PCV at 53.0 $\pm 1.5 \%$ (Table 1), and the group with the highest dosage had the highest level, and it was $53.3 \pm 1.6 \%$ (Table 1). The Mean Cell Volume of the test subjects differed as well. The highest observation was taken in the control group with the $128 \pm 4.6 \%$ (Table 1) MCV. The volume in the second group with $250 \mathrm{mg} / \mathrm{kg}$ dosage was $117 \pm 5.0 \mathrm{fl}$ (Table 1). The third group had the MCV at $110 \pm 3.7 \mathrm{fl}$ (Table 1), and the group with the highest dosage had the highest level, and it was 114 $\pm 2.3 \mathrm{fl}$ (Table 1). The Mean Corpuscular Haemoglobin was next in line.

Table 1. Hematological parameters and their mean values \pm standard deviation.

\begin{tabular}{l|l|l|l|l} 
Parameters & Control (Mean \pm SD) & $\begin{array}{l}\mathbf{2 5 0 m g} / \mathbf{k g} \\
(\text { Mean } \pm \text { SD) }\end{array}$ & $\begin{array}{l}\mathbf{5 0 0 m g} / \mathbf{k g} \\
(\text { Mean } \pm \text { SD) }\end{array}$ & $\begin{array}{l}\mathbf{1 0 0 0 m g} / \mathbf{k g} \\
(\mathbf{M e a n} \pm \text { SD) }\end{array}$ \\
\hline $\mathrm{RBC}\left(\times 10^{6} / \mathrm{mm}^{3}\right)$ & $4.03 \pm 0.208$ & $4.50 \pm 0.293$ & $4.680 \pm 0.190$ & $4.84 \pm 0.243$ \\
\hline $\mathrm{WBC}\left(\times 10^{3} / \mathrm{mm}^{3}\right)$ & $8.16 \pm 0.39$ & $8.06 \pm 0.39$ & $7.80 \pm 0.41$ & $7.76 \pm 0.44$ \\
\hline $\mathrm{Hb}(\mathrm{g} / \mathrm{dl})$ & $12.52 \pm 0.7$ & $12.87 \pm 0.41$ & $13.14 \pm 0.57$ & $13.40 \pm 0.47$ \\
\hline Neutrophils $(\%)$ & $17 \pm 3$ & $17 \pm 3$ & $19 \pm 3$ & $20 \pm 3$ \\
\hline Eosinophils $(\%)$ & $0.2 \pm 0.1$ & $0.1 \pm 0.1$ & $0 \pm 0$ & $0 \pm 0$ \\
\hline Basophil $(\%)$ & 0 & 0 & 0 & 0 \\
\hline Lymphocyte $(\%)$ & $80 \pm 3$ & $81 \pm 3$ & $83 \pm 3$ & $83 \pm 3$ \\
\hline Monocyte $(\%)$ & 0 & 0 & 0 & 0 \\
\hline PCV $(\%)$ & $50.9 \pm 1.6$ & $51.6 \pm 1.6$ & $53.0 \pm 1.5$ & $53.3 \pm 1.6$ \\
\hline $\mathrm{MCV}(\mathrm{fl})$ & $128 \pm 4.6$ & $117 \pm 5.0$ & $110 \pm 3.7$ & $114 \pm 2.3$ \\
\hline $\mathrm{MCH}(\mathrm{pg})$ & $28.11 \pm 1.0$ & $27.51 \pm 1.44$ & $28.71 \pm 0.4$ & $32.25 \pm 0.77$ \\
\hline $\mathrm{MCHC}(\%)$ & $24.10 \pm 0.76$ & $24.73 \pm 0.65$ & $25.13 \pm 0.37$ & $25.33 \pm 0.5$
\end{tabular}

Abbreviations: RBC- Red Blood Cell, WBC- White Blood Cell, Hb- Haemoglobin, PCV- Packed cell Volume, MCV- Mean Corpuscular Volume, MCH- Mean Corpuscular Haemoglobin, MCHC- Mean Corpuscular Haemoglobin Concentration. 
The observation of the control group was $28.11 \pm 1.0 / \mathrm{pg}$ (Table 1). The volume in the second group with $250 \mathrm{mg} / \mathrm{kg}$ dosage was $27.51 \pm 1.44 \mathrm{pg}$ (Table 1). The third group had the $\mathrm{MCH}$ at 28.71 $\pm 0.4 \mathrm{pg}$ (Table 1), and the group with the highest dosage had the highest level, and it was $32.25 \pm 0.77 \mathrm{pg}$ (Table 1).

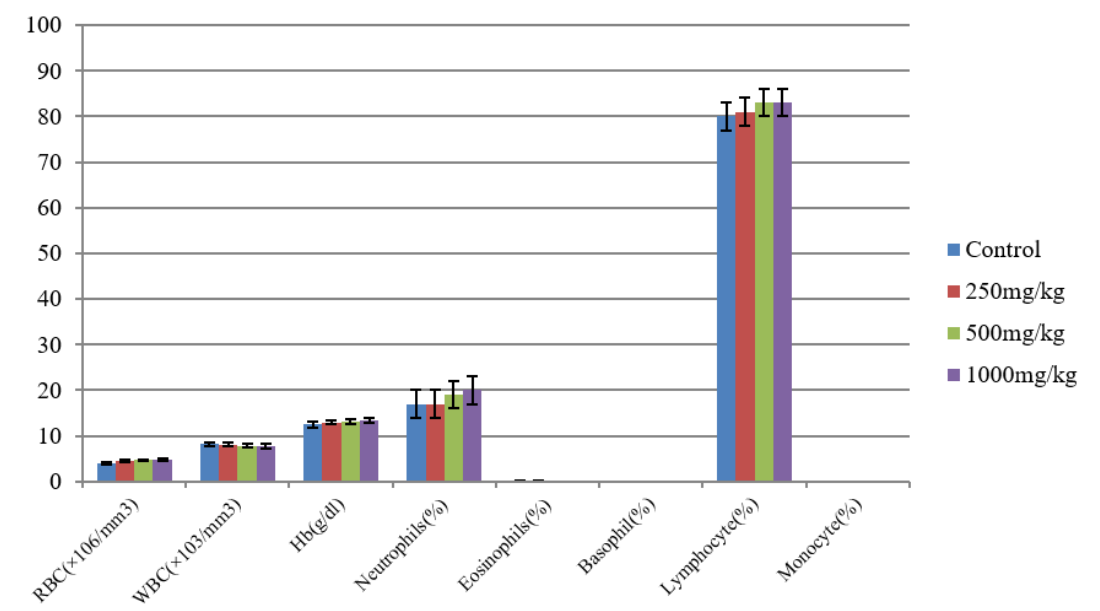

Figure 1. Graph showing the different parameters (RBC, WBC, and DLC count) in Mean \pm SD.

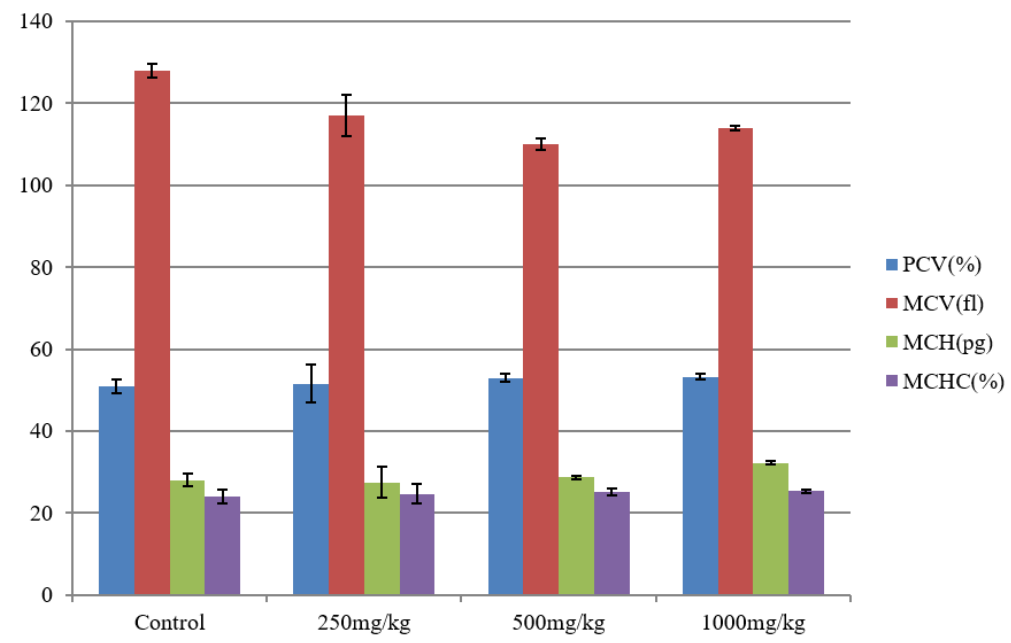

Figure 2. Graph showing the different parameters (PCV, MCV, $\mathrm{MCH}$, and $\mathrm{MCHC}$ ) in $\mathrm{Mean} \pm \mathrm{SD}$.

The control group of the experiment displayed results that resembled the observations made by certain researchers in the past. According to work done [23] to obtain the reference values for mice hematology, the Haemoglobin value (12.52 \pm 0.7$)$ of the present study was less than the one obtained in their experiment $(13.63 \pm 1.4)$, the similar could be said about the Neutrophils percentage, which was $22.64 \pm 6.4$. The Haemoglobin value was nearly similar to the control mice's hemoglobin value in research conducted [24]. The lymphocyte percentage was 75.17 \pm 6.6 , which was in agreement with the values obtained in the control group of the present study. The $\mathrm{MCH}$ of the mentioned research work was $26.53 \pm 4.8$, which was similar to that obtained in the present work. In an experiment by [25], the lymphocyte count of the control mice was 78.7 \pm 6.7 , nearly similar to the control of the present study, and the same goes for the Haemoglobin control value, which was also nearly similar to the control value of the mentioned experiment, $11.5 \pm 0.40$. The RBC value elevated along with the Vitamin $\mathrm{C}$ treatment, and an identical course was followed by the hemoglobin value, which also elevated (Figure 1) with the higher dose. The WBC experienced the opposite effect; the WBC values were decreasing(Figure 1) with the administration of the Vitamin C. In the differential count of WBC, the Neutrophils percentage was similar (Table 1)in the control and the $250 \mathrm{mg} / \mathrm{kg}$ and 
then it increased with the treatment. The eosinophil percentage was negligibly low(Table 1) and in control, and there were no eosinophils observed on the treated mice. The lymphocyte had a small elevation(Figure 1) with the treatment values. The basophil count was not available, and the monocyte count was also zero(Table 1), indicating the absence of those cells in the blood of the test subjects. This was in agreement with the findings of [26]. The PCV value of the control group was $50.9 \pm 1.6$ (Table 1), which is nearly similar to the control PCV value $(49.32 \pm 3.21)$ of the work done, and the MCHC value was found to be in ascending with the increase in the concentration of the dosage (Figure 2), and the control value was close to the control value in the research work of [27]. The PCV values elevated as well, which is in agreement with the work done, and the $\mathrm{MCH}$ followed an increasing pattern, as in the case of [28] research work with a small dip in the value of the $250 \mathrm{mg} / \mathrm{kg}$ concentration(Figure 2) where there was a hike in the PVC value(Figure 2) after treatment with Vitamin C, in comparison to the control. The MCV followed a decreasing pattern, with a small dip in the value of the $500 \mathrm{mg} / \mathrm{kg}$ concentration. The decline in the MCV value (Figure 2) could likely be because of the rise in the RBC count [29] on Vitamin C treatment.

\section{Conclusions}

The treatment of the mice with Vitamin $\mathrm{C}$ indicates an overall positive effect on the various parameters taken into consideration, so it is evident that the administration of Vitamin $\mathrm{C}$ can be helpful for research on toxicity in drugs and to study the long term impact of pharmaceuticals. The study also indicates that a higher Vitamin $\mathrm{C}$ intake could have beneficial results at a hematological level.

\section{Funding}

This research received no external funding.

\section{Acknowledgments}

Both the authors acknowledged the Head, Department of Pharmacology, Centurion University of Technology and Management, Odisha, India, for the experiment by using the animal house.

\section{Conflicts of Interest}

The authors declare no conflict of interest.

\section{References}

1. Mousavi, S.; Bereswill, S.; Heimesaat, M.M. Immunomodulatory and antimicrobial effects of vitamin C. Eur. J. Microbiol. Immunol. (Bp) 2019, 9, 73-79,https://doi.org/10.1556/1886.2019.00016.

2. Ekeh, F.N.; Ekechukwu, N.E.; Chukwuma, C.F.; Aguzie, I.O.N.; Ohanu, C.M.; Ebido, C.; Oluah, S.N. Mixed vitamin $\mathrm{C}$ and zinc diet supplements co-administered with artemether drug improved haematological profile and survival of mice infected with Plasmodium berghei. Food Science and Human Wellness 2019, 8, 275-282, https://doi.org/10.1016/j.fshw.2019.05.003.

3. Nechuta, S.; Lu, W.; Chen, Z.; Zheng, Y.; Gu, K.; Cai, H.; Zheng, W.; Shu, X.O. Vitamin Supplement Use During Breast Cancer Treatment and Survival: A Prospective Cohort Study. Cancer Epidemiol. Biomarkers Prev. 2011, 20, 262,https://doi.org/10.1158/1055-9965.EPI-10-1072.

4. Sharma, P. Vitamin C Rich Fruits Can Prevent Heart Disease. Indian J. Clin. Biochem. 2013, 28, 213-214, https://doi.org/10.1007/s12291-013-0351-y.

5. Hallberg, L.; Brune, M.; Rossander-Hulthén, L. Is There a Physiological Role of Vitamin C in Iron absorption? Ann. N. Y. Acad. Sci. 1987, 498, 324-332, https://doi.org/10.1111/j.1749-6632.1987.tb23771.x. 
6. Diaz, M.N.; Frei, B.; Vita, J.A.; Keaney, J.F. Antioxidants and Atherosclerotic Heart Disease. New Engl. J. Med. 1997, 337, 408-416,https://doi.org/10.1056/NEJM199708073370607.

7. Padayatty, S.J.; Katz, A.; Wang, Y.; Eck, P.; Kwon, O.; Lee, J.-H.; Chen, S.; Corpe, C.; Dutta, A.; Dutta, S.K., et al. Vitamin C as an Antioxidant: Evaluation of Its Role in Disease Prevention. J. Am. Coll. Nutr. 2003, 22, 18-35, https://doi.org/10.1080/07315724.2003.10719272.

8. Bukkuri, A. A mathematical model showing the potential of vitamin c to boost the innate immune response. Open Journal of Mathematical Sciences 2019, 3, https://doi.org/10.30538/oms2019.0067.

9. Carr, A.C. A new clinical trial to test high-dose vitamin C in patients with COVID-19. Critical Care 2020, 24, 133,https://doi.org/10.1186/s13054-020-02851-4.

10. Morse, H.C. Chapter 1 - Building a Better Mouse: One Hundred Years of Genetics and Biology. In The Mouse in Biomedical Research (Second Edition), Fox, J.G., Davisson, M.T., Quimby, F.W., Barthold, S.W., Newcomer, C.E., Smith, A.L., Eds. Academic Press: Burlington, 2007;pp. 111,https://doi.org/10.1016/B978-012369454-6/50013-3.

11. Chinwalla, A.T.; Cook, L.L.; Delehaunty, K.D.; Fewell, G.A.; Fulton, L.A.; Fulton, R.S.; Graves, T.A.; Hillier, L.W.; Mardis, E.R.; McPherson, J.D.; Miner, T.L.; Nash, W.E.; Nelson, J.O.; Nhan, M.N.; Pepin, K.H.; Pohl, C.S.; Ponce, T.C.; Schultz, B.; Thompson, J.; Trevaskis, E.; Waterston, R.H.; Wendl, M.C.; Wilson, R.K.; Yang, S.-P. ; An, P.; Berry, E.; Birren, B.; Bloom, T.; Brown, D.G.; Butler, J.; Daly, M.; David, R.; Deri, J.; Dodge, S.; Foley, K.; Gage, D.; Gnerre, S.; Holzer, T.; Jaffe, D.B.; Kamal, M.; Karlsson, E.K.; Kells, C.; Kirby, A.; Kulbokas, E.J.; Lander, E.S.; Landers, T.; Leger, J.P.; Levine, R.; Lindblad-Toh, K.; Mauceli, E.; Mayer, J.H.; McCarthy, M.; Meldrim, J.; Meldrim, J.; Mesirov, J.P.; Nicol, R.; Nusbaum, C.; Seaman, S.; Sharpe, T.; Sheridan, A.; Singer, J.B.; Santos, R.; Spencer, B.; Stange-Thomann, N.; Vinson, J.P.; Wade, C.M.; Wierzbowski, J.; Wyman, D.; Zody, M.C.; Birney, E.; Goldman, N.; Kasprzyk, A.; Mongin, E.; Rust, A.G.; Slater, G.; Stabenau, A.; Ureta-Vidal, A.; Whelan, S.; Ainscough, R.; Attwood, J.; Bailey, J.; Barlow, K.; Beck, S.; Burton, J.; Clamp, M.; Clee, C.; Coulson, A.; Cuff, J.; Curwen, V.; Cutts, T.; Davies, J.; Eyras, E.; Grafham, D.; Gregory, S.; Hubbard, T.; Hunt, A.; Jones, M.; Joy, A.; Leonard, S.; Lloyd, C.; Matthews, L.; McLaren, S.; McLay, K.; Meredith, B.; Mullikin, J.C.; Ning, Z.; Oliver, K.; Overton-Larty, E.; Plumb, R.; Potter, S.; Quail, M.; Rogers, J.; Scott, C.; Searle, S.; Shownkeen, R.; Sims, S.; Wall, M.; West, A.P.; Willey, D.; Williams, S.; Abril, J.F.; Guigó, R.; Parra, G.; Agarwal, P.; Agarwala, R.; Church, D.M.; Hlavina, W.; Maglott, D.R.; Sapojnikov, V.; Alexandersson, M.; Pachter, L.; Antonarakis, S.E.; Dermitzakis, E.T.; Reymond, A.; Ucla, C.; Baertsch, R.; Diekhans, M.; Furey, T.S.; Hinrichs, A.; Hsu, F.; Karolchik, D.; Kent, W.J.; Roskin, K.M.; Schwartz, M.S.; Sugnet, C.; Weber, R.J.; Bork, P.; Letunic, I.; Suyama, M.; Torrents, D.; Zdobnov, E.M.; Botcherby, M.; Brown, S.D.; Campbell, R.D.; Jackson, I.; Bray, N.; Couronne, O.; Dubchak, I.; Poliakov, A.; Rubin, E.M.; Brent, M.R.; Flicek, P.; Keibler, E.; Korf, I.; Batalov, S.; Bult, C.; Frankel, W.N.; Carninci, P.; Hayashizaki, Y.; Kawai, J.; Okazaki, Y.; Cawley, S.; Kulp, D.; Wheeler, R.; Chiaromonte, F.; Collins, F.S.; Felsenfeld, A.; Guyer, M.; Peterson, J.; Wetterstrand, K.; Copley, R.R.; Mott, R.; Dewey, C.; Dickens, N.J.; Emes, R.D.; Goodstadt, L.; Ponting, C.P.; Winter, E.; Dunn, D.M.; von Niederhausern, A.C.; Weiss, R.B.; Eddy, S.R.; Johnson, L.S.; Jones, T.A.; Elnitski, L.; Kolbe, D.L.; Eswara, P.; Miller, W.; O’Connor, M.J.; Schwartz, S.; Gibbs, R.A.; Muzny, D.M.; Glusman, G.; Smit, A.; Green, E.D.; Hardison, R.C.; Yang, S.; Haussler, D.; Hua, A.; Roe, B.A.; Kucherlapati, R.S.; Montgomery, K.T.; Li, J.; Li, M.; Lucas, S.; Ma, B.; McCombie, W.R.; Morgan, M.; Pevzner, P.; Tesler, G.; Schultz, J.; Smith, D.R.; Tromp, J.; Worley, K.C.; Lander, E.S.; Abril, J.F.; Agarwal, P.; Alexandersson, M.; Antonarakis, S.E.; Baertsch, R.; Berry, E.; Birney, E.; Bork, P.; Bray, N.; Brent, M.R.; Brown, D.G.; Butler, J.; Bult, C.; Chiaromonte, F.; Chinwalla, A.T.; Church, D.M.; Clamp, M.; Collins, F.S.; Copley, R.R.; Couronne, O.; Cawley, S.; Cuff, J.; Curwen, V.; Cutts, T.; Daly, M.; Dermitzakis, E.T.; Dewey, C.; Mouse Genome Sequencing, C.; Genome Sequencing, C.; Whitehead Institute, M.I.T.C.f.G.R.; European Bioinformatics, I.; Wellcome Trust Sanger, I.; Research Group in Biomedical, I.; Bioinformatics; National Center for Biotechnology, I.; Department of, M.; Division of Medical, G.; Center for Biomolecular, S.; Engineering; Embl; Consortium, U.M.M.S.; Lawrence Berkeley National, L.; Department of Computer, S.; School of Computer, S.; The Jackson, L.; Laboratory for Genome, E.; Affymetrix, I.; Departments of, S.; Health Evaluation, S.; National Human Genome Research, I.; Wellcome Trust Centre for Human, G.; Department of Electrical, E.; Department of Human, A.; Genetics; Department of Human, G.; Howard Hughes Medical, I.; Department of, G.; Departments of, B.; Molecular, B.; Computer, S.; Engineering; Department of Computer, S.; Engineering; Baylor College of, M.; The Institute for Systems, B.; Department of, B.; Molecular, B.; Howard Hughes Medical, I.; Department of, C.; Biochemistry; Departments of, G.; Medicine; Harvard-Partners Center for, G.; Genomics; Department of, S.; Institute, U.D.J.G.; Cold Spring Harbor, L.; Wellcome, T.; Max Planck Institute for Molecular, G.; Genome Therapeutics, C.; Bioinformatics Solutions, I.; Department of, M.; Human, G.; Department of, B.; Members of the Mouse Genome Analysis, G. Initial sequencing and comparative analysis of the mouse genome. Nature 2002, 420, 520562,https://doi.org/10.1038/nature01262.

12. Fox, J.G.; Barthold, S.W.; Davisson, M.T.; Newcomer, C.E.; Quimby, F.W.; Smith, A.L. The Mouse in Biomedical Research. Elsevier Inc.; 2007; https://ucdavis.pure.elsevier.com/en/publications/the-mouse-inbiomedical-research. 
13. Pallauf, K.; Bendall, J.K.; Scheiermann, C.; Watschinger, K.; Hoffmann, J.; Roeder, T.; Rimbach, G. Vitamin $\mathrm{C}$ and lifespan in model organisms. Food Chem. Toxicol. 2013, 58, 255-263, https://doi.org/10.1016/j.fct.2013.04.046.

14. Perlman, R.L. Mouse models of human disease: An evolutionary perspective. Evolution, Medicine, and Public Health 2016, 2016, 170-176,https://doi.org/10.1093/emph/eow014.

15. Parida, S.P.; Dutta, S.K.; Pal, A. Hematology and plasma biochemistry of wild-caught Indian cobra Naja naja (Linnaeus, 1758). J. Venom. Anim. Tox. incl. Trop. Dis. 2014, 20, 14,https://doi.org/10.1186/16789199-20-14.

16. Parida, S.P.; Dutta, S.K.; Pal, A. Hematology and plasma chemistry of wild Keeled Indian Mabuya, Eutropis carinata (Schneider 1801). Comp. Clin. Path. 2013, 22, 869-873,https://doi.org/10.1007/s00580-012-1490$\mathrm{X}$.

17. Pal, A.; Parida, S.; Swain, M. Hematological and plasma biochemistry in fan throated lizard Sitana ponticeriana (Sauria: Agamidae). Russ. J. Herpetol. 2018, 15, 110-116.

18. Parida, S.P.; Dutta, S.K.; Pal, A. Hematological and plasma biochemistry in Psammophilus blanfordanus (Sauria: Agamidae). Comp. Clin. Path. 2012, 21, 1387-1394,https://doi.org/10.1007/s00580-011-1303-7.

19. Hemilä, H.; Chalker, E. Vitamin C as a Possible Therapy for COVID-19. Infect Chemother 2020, 52, 222223,https://doi.org/10.3947/ic.2020.52.2.222.

20. National Research Council. Guide for the Care and Use of Laboratory Animals: Eighth Edition; The National Academies Press: Washington, DC, 2011;https://doi.org/10.17226/12910.

21. Nemzek, J.A.; Bolgos, G.L.; Williams, B.A.; Remick, D.G. Differences in normal values for murine white blood cell counts and other hematological parameters based on sampling site. Inflammation Res. 2001, 50, 523-527,https://doi.org/10.1007/PL00000229.

22. Wolforth, J. Methods of Blood Collection in the Mouse. Lab Animal 2000, 29, 47-53.

23. Delwatta, S.L.; Gunatilake, M.; Baumans, V.; Seneviratne, M.D.; Dissanayaka, M.L.B.; Batagoda, S.S.; Udagedara, A.H.; Walpola, P.B. Reference values for selected hematological, biochemical and physiological parameters of Sprague-Dawley rats at the Animal House, Faculty of Medicine, University of Colombo, Sri Lanka. Animal Models and Experimental Medicine 2018, 1, 250-254, https://doi.org/10.1002/ame2.12041.

24. Brahmi, N.; Saoudi, M.; Kadri, Y.; Kallel, C.; Euch, A.E.; Ayadi, F.M.; Harrath, A.H.; El Feki, A.; Allagui, M.S. Protective effect of Chaetomorpha gracilis aqueous extract against erythrocytes oxidative damage induced by high fat diet in treated mice. Arch. Physiol. Biochem. 2019, 125, 220227,https://doi.org/10.1080/13813455.2018.1448997.

25. Abouelghar, G.E.; El-Bermawy, Z.A.; Salman, H.M.S. Oxidative stress, hematological and biochemical alterations induced by sub-acute exposure to fipronil ( $\left.\mathrm{COACH}{ }^{\circledR}\right)$ in albino mice and ameliorative effect of selenium plus vitamin E. Environmental Science and Pollution Research 2020, 27, 7886-7900, https://doi.org/10.1007/s11356-019-06579-9.

26. Santos, E.W.; Oliveira, D.C.D.; Hastreiter, A.; Silva, G.B.D.; Beltran, J.S.D.O.; Tsujita, M.; Crisma, A.R.; Neves, S.M.P.; Fock, R.A.;Borelli, P. Hematological and biochemical references values for C57BL/6, Swiss Webster and BALB/c mice, Brazilian Journal of Veterinary Research and Animal Science 2016, 53, 138145. https://doi.org/10.11606/issn.1678-4456.v53i2p138-145.

27. Chelly, M.; Chelly, S.; Ben Salah, H.; Athmouni, K.; Bitto, A.; Sellami, H.; Kallel, C.; Allouche, N.; Gdoura, R.; Bouaziz-Ketata, H. Characterization, antioxidant and protective effects of edible Rumex roseus on erythrocyte oxidative damage induced by methomyl. Journal of Food Measurement and Characterization 2020, 14, 229-243, https://doi.org/10.1007/s11694-019-00285-3.

28. Reddy, K.B.A.K.; Jeevanalatha, M.; Lakshman, M.; Rani, M.U. The Toxic Effects of Paraquat (PQ) on Body Weights and Haematological Parameters in Male Albino Wistar Rats and its Amelioration with Vitamin C. Int. J. Curr. Microbiol. App. Sci 2019, 8, 314-320,https://doi.org/10.20546/ijcmas.2019.811.039.

29. Andrew, G.S.; Simon, U.T.; John, A.U.; Godwin, O.O.; Alexander, N.I.; Ikagu, Y.M. Studies on changes in some haematological and plasma biochemical parameters in wistar rats fed on diets containing calcium carbide ripened mango fruits. Int. J. of Food Sci. and Nutri. Eng.2018, 8, 27-36. https://doi.org/10.5923/j.food.20180802.02. 